\title{
Report of ciliate epibionts (Ciliophora, Suctorea) on meiobenthic invertebrates from the Indian coast near Karwar, Karnataka
}

\author{
Tapas Chatterjee ${ }^{1}$, Igor Dovgal ${ }^{2}$ and Mandar Nanajkar ${ }^{3}$ \\ ${ }^{1}$ Crescent International School, Bario, Govindpur, Dhanbad 828109, Jharkhand, \\ India \\ ${ }^{2}$ A.O. Kovalevsky Institute of Biology of the Southern Seas RAS, Sevastopol, 299011, \\ Russia \\ ${ }^{3}$ CSIR, National Institute of Oceanography, Dona Paula, Goa-403004, India
}

| Submitted March 16, 2020 | Accepted April 17, 2020|

\begin{abstract}
Summary
The article describes four epibiont suctorian ciliates, viz. Thecacineta cothurnioides (Collin, 1909) and Trematosoma rotunda (Allgén, 1952) on the nematode Tricoma sp., Thecacineta calix (Schröder, 1907) and Acineta tuberosa Ehrenberg, 1834 on the harpacticoid copepod, from the Karwar coast of India (Karnataka state), the Arabian Sea. Trematosoma rotunda is reported here first time as epibiont on the genus Tricoma representative. The systematic positions of the found suctorian species, their brief descriptions, measurements, and data on their distribution, hosts and localisations at the host body are presented.
\end{abstract}

Key words: ciliate epibiont, marine meiobenthos, India, Suctorea

\section{Introduction}

The phenomenon of epibiosis is common in marine biocenoses, and suctorian ciliates belong to epibiont ciliates that most frequently occur in aquatic habitats. Suctorians can be found on a wide diversity of hosts and substrates. The majority of these ciliates are commensals of various water invertebrates or vertebrates (Dovgal, 2002, 2013).

Epibiont ciliates from the west coast of India were studied by many authors (Santhakumari 1985, 1986; Chatterjee, 1996; Dovgal et al., 2008, 2009; Chatterjee et al., 2013, 2019a, 2019b,).
The present article reports four suctorian ciliate species inhabiting meiobenthic invertebrate hosts (harpacticoid copepods and nematodes) from the Karwar coast of the Arabian Sea, Karnataka state, India.

\section{Material and methods}

The study area is located 5 kilometres south of Karwar (District: Uttar Kannada, Karnataka), Latitude: $14^{\circ} 46^{\prime} 38.57^{\prime}$ N N, Longitude: $74^{\circ} 06$ '59.92"E, which is near the Goa-Karnataka border, west coast 
of India. The mouth of the river Kali is located close to Karwar. The study area is a subtidal region of a small bay (Fig. 1), which is lined by Kamat beach towards east. The composition of sediment was $81.6 \%$ sand, $3.4 \%$ silt and $13.2 \%$ clay. The bottom water temperature was $30.6^{\circ} \mathrm{C}$, salinity $34.9 \%$, and $\mathrm{pH} 7.1$. The dissolved oxygen amounted $6.5 \mathrm{mg} / \mathrm{l}$ in the bottom water. The organic carbon at the location was $0.17 \%$. The water depth at this location was $7 \mathrm{~m}$ in the study period (April 2019, Premonsoon).

The samples of the top layer of sediment were collected with the aid of a Van-Veen grab. Subsampling of the sediment with meiofauna was done with an acrylic core of $4.5 \mathrm{~cm}$, and the samples were immediately preserved with buffered formalin-Rose Bengal solution until further laboratory analysis. Meiofaunal organisms infected by ciliates were individually picked under an Olympus dissecting microscope. Measurements were carried out using the program Toup View 3.7 for digital camera. The systematic position of suctorian ciliates follows Dovgal $(2002,2013)$. Specimens are kept in the collection of the third author (MN).

\section{Results and discussion}

Class Suctorea Claparéde et Lachmann, 1859

Subclass Exogenia Collin, 1912

Order Vermigemmida Jankowski, 1973

Family Thecacinetidae Matthes, 1956

Genus Thecacineta Collin, 1909

Thecacineta cothurnioides (Collin, 1909) (Fig. 2A)

Material examined. Numerous individuals of species are evenly distributed throughout the body surface of the nematode Tricoma sp.

Brief description. Marine loricate suctorian. Cell body entirely fills the lorica and attaches to its base. Apical part of the body conical. About 15 tentacles arise from the apical surface of body slightly projecting from the lorica. Macronucleus spherical in shape, located in the basal region of the cell. Contractile vacuole small, single and placed near macronucleus. Lorica smooth. Stalk long, slightly curved, equipped with very small widening (physon) in the junction with lorica.

Measurements based on four individuals (in $\mu \mathrm{m})$ : lorica length $37-42$, lorica width $18-23$, lorica mouth diameter 8-13, stalk length 9-18, stalk diameter 2 , macronucleus diameter 7 , tentacle length 3-7.

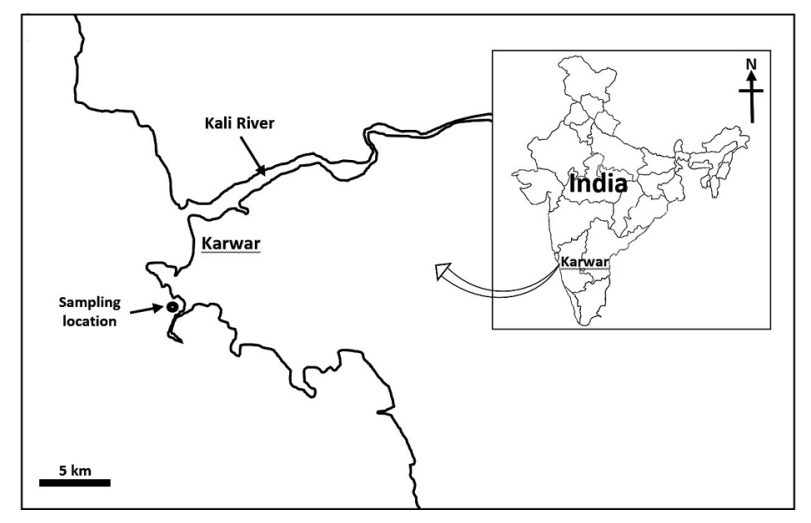

Fig. 1. Map of meiobenthos sampling location near Karwar, west coast of India, the Arabian Sea.

Remarks. Collin (1909) firstly described this species on the harpacticoid copepod Cletodes longicaudatus (Boeck, 1872) from Banyuls-surMer at the Mediterranean coast of France. Dovgal et al. (2009) reported this species from Ratnagiri, Maharastra state of India, Arabian Sea, centralwest coast of India on the nematode Tricoma sp. Bhattacharjee (2014) reported this species from Rushikulya (Odisha State of India), north-western Bay of Bengal on the nematodes Chromaspirina sp. The present article recorded the new locality of $T$. cothurnioides from Karwar, Karnataka state of the west coast of India.

Thecacineta calix (Schröder, 1907) (Fig. 2 B)

Material examined. Two individuals found on a harpacticoid copepod, attached near the furca region of the host.

Brief description. Marine loricate suctorian. Cell body entirely fills the lorica and attach to its base. Apical part of body protrudes beyond the lorica aperture. Clavate tentacles (up to 30 ) arise from the apical surface of body. The walls of the lorica are covered with transverse ribs. Macronucleus ovoid, located in the basal region of the cell. Large contractile vacuole located in the basal region of the cell, usually near macronucleus.

Measurements based on two individuals (in $\mu \mathrm{m}$ ): lorica length $77-120$, lorica width $37-46$, lorica mouth diameter $28-41$, stalk length $12-21$, stalk diameter 3-4, body length 75-103, body width 20-23, macronucleus diameter 10-13.

Remarks. T. calix has been reported as an epibiont on nematodes, copepods, and halacarid mites from the Atlantic, Pacific, Antarctic and Indian Oceans, from the intertidal region to the 


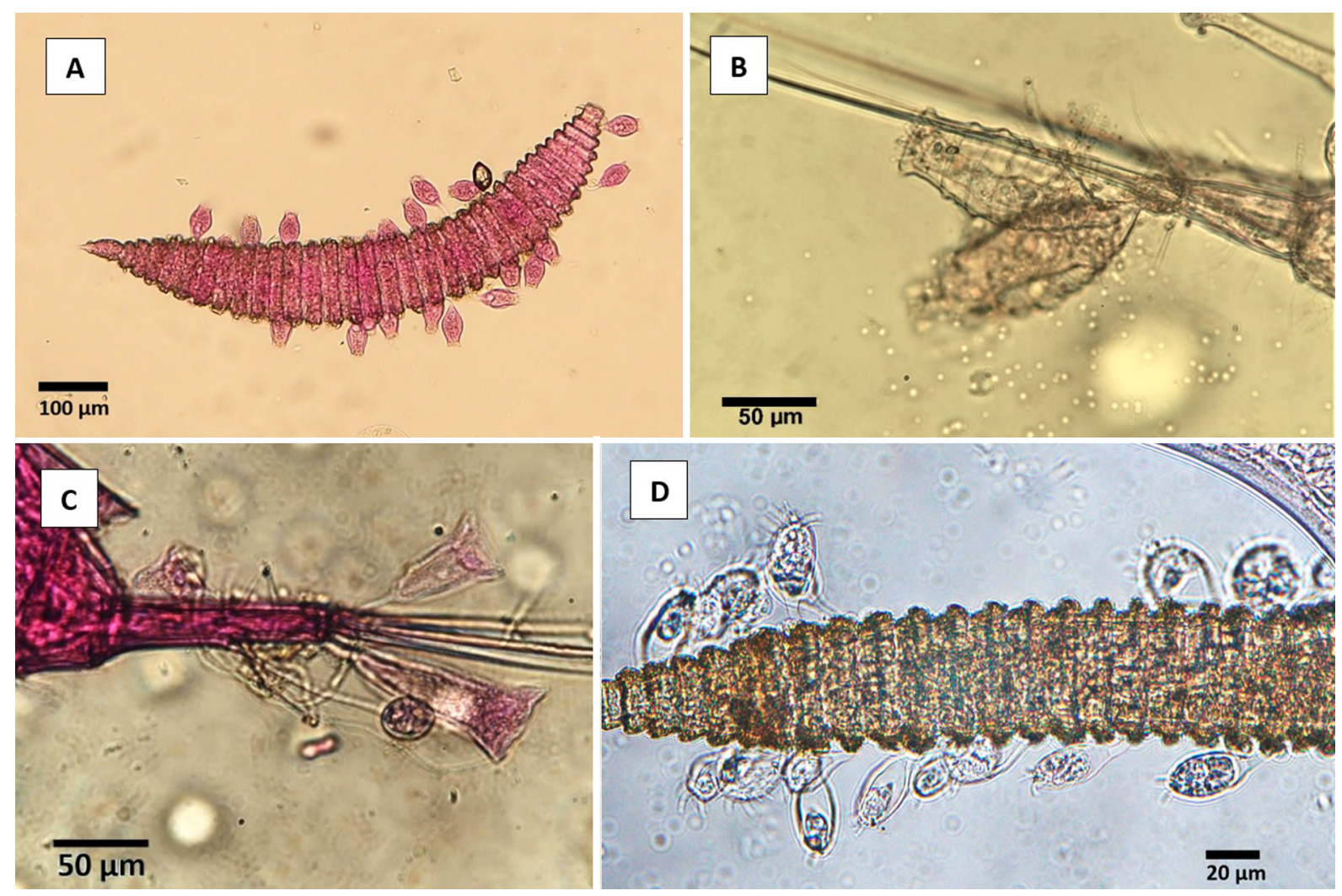

Fig. 2. Ciliate species found near Karwar, Indian coast. A - Thecacineta cothurnioides (Collin, 1909) on Tricoma sp.; B - Thecacineta calix (Schröder, 1907) on harapacticoid copepod; C - Acineta tuberosa Ehrenberg, 1834 on furca of harpacticoid copepod; D - Trematosoma rotunda (Allgén, 1952) on Tricoma sp.

deep sea. Details of distribution and host specificity of this species are given in Chatterjee et al. (2019).

\section{Subclass Endogenia Collin, 1012 \\ Order Acinetida Raabe, 1964 \\ Family Acinetidae Ehrenberg, 1834 \\ Genus Acineta Ehrenberg, 1834}

\section{Acineta tuberosa Ehrenberg, 1834 (Fig. 2 C)}

Material examined. Two individuals found on a harpacticoid copepod, attached near the furca region of the host.

Brief description. Suctorian ciliate with a smooth, triangular or cup-shaped, laterally flattened lorica. The lorica aperture is dumbbell-shaped. The upper half of the lorica is characterized by sharp widening. The body is attached to the bottom of the lorica. Macronucleus spherical or elongated, medial, located along the longitudinal axis of the cell. The single contractile vacuole located subapically, above the macronucleus. The stalk is long, sometimes curved, equipped with a well-developed attachment disk. In the area of connection with the lorica, the stalk is somewhat widened, in some cases might be dipped to the base of the shell.

Measurements based on two individuals (in $\mu \mathrm{m}$ ): lorica length 57-96, lorica width 22-36, lorica mouth width 38-45, stalk length $18-24$, stalk diameter 4-5, macronucleus diameter 14 .

Remarks. The species was reported from marine and brackish waters as periphytic or nonspecific commensals of various aquatic invertebrates (Dovgal, 2013).

In India, this species was reported from Andhra Pradesh coast (Bay of Bengal) as epiphytic on algae (Radhakrishna, 1984; Kalavati and Raman, 2008). Chatterjee et al. (2013) reported this species on a harpacticoid copepod from the Dias beach, Dona Paula, Goa, India (the Arabian sea).

Genus Trematosoma Batisse, 1972

Trematosoma rotunda (Allgén, 1952) (Fig. 2 D) 
Material examined. Numerous individuals distributed throughout the body surface of the nematode Tricoma sp.

Brief description. Marine loricate suctorian. Cell body short, rounded, laterally flattened, entirely fills up the lorica and clamped to their aperture border. Lorica delicate, gently striated. Tentacles clavate, short, arranged at the upper body surface as a row in two groups. Macronucleus spherical or oval, centrally located. Stalk short, thin, slightly ribbed.

Measurements based on four individuals (in $\mu \mathrm{m})$ : lorica length $26-29$, lorica width 14-22, body length 19-39, body width 11-20, stalk length 5-15, stalk diameter 3-4, macronucleus diameter 6-8, length of tentacles $3-12$.

Remarks. Allgén (1952) reported this species from Falkland Islands, located near the southern tip of Argentina and Antarctic Peninsula (Graham Land) on the nematodes Desmodora tenuispiculum Allgén, 1928 and D. stateni Allgén, 1928, respectively. Dovgal et al. (2009) provided remarks on systematics and nomenclature of this species. This species was reported from Ratnagiri, Maharastra, west coast of India, the Arabian Sea, as epibiont on the nematodes Pseudochromadora sp. (Dovgal et al., 2009). The above-mentioned authors also identified this species from the intertidal zone of North-Eastern Queensland, Australia, based on microphotograph of Fisher (2003). Bhattacharjee (2014) reported it at the coast of Rushikulya (Odisha State of India) on the nematode Chromaspirina sp. Ansari and Bhadury (2016) reported it from the mangrove ecosystem of Sagar Island of Sundarbans from the north-western Bay of Bengal, on the nematodes Dorylaimposis punctata. Ghosh and Mandal (2019) reported it on the nematodes Desmodora scaldensis de Man, 1889 from the subtidal region of the Matla estuary, Sundarbans, Bay of Bengal. In the present record, this species was registered near Karwar, Karnataka state of the west coast of India, on the nematode Tricoma sp. Trematosoma rotunda is reported here first time as an epibiont on the host from the genus Tricoma.

\section{Acknowledgements}

Second author's (ID) work was fulfilled within the framework of research topic \#AAAA-A19119060690014-5 at A.O. Kovalevsky Institute of Biology of the Southern Seas RAS.

\section{References}

Allgén C.A. 1952. Uber zwei neue antarktische Suctorien aus dem Gracham Land. K. Fysiograf. Sälls. i Lund Forhändl. 21 (18), 173-176.

Ansari K.G.M.T. and Bhadury P. 2016. Occurrence of epibionts associated with meiofaunal basibionts from the world's largest mangrove ecosystem, the Sundarbans. Mar. Biodiver. 47, 539-548.

Bhattacharjee D. 2014. Suctorian epibionts on Chromaspirina sp. (Nematoda: Desmodoridae) from the shallow continental shelf of the Bay of Bengal, northern Indian Ocean. Mar. Biodivers. Rec. 7 (e49), 1-3.

Chatterjee T. 1996. Ciliate infestation on the phytal Halacaridae (Acari) from the Kovalam Beach (Kerala coast). J. Bombay Nat. Hist. Soc. 93, 107-108.

Chatterjee T., Fernandez-Leborans G., Ramteke D. and Ingole B.S. 2013. New records of epibiont Ciliates (Ciliophora) from Indian coast with descriptions of six new species. Cah. Biol. Mar. 54, 143-159.

Chatterjee T., Nanajkar M. and Dovgal I. 2019a. New record of Loricophyra stresemanni (Ciliophora: Suctorea) as epibiont on nematodes from the Indian Ocean and notes on the genus Loricophrya. Cah. Biol. Mar. 60, 283-288.

Chatterjee T., Nanajkar M., Dovgal I., Sergeeva N. and Bhave S. 2019b. New records of epibiont Thecacineta calix (Ciliophora: Suctoria) from the Caspian Sea and Angria Bank, Arabian Sea. Cah. Biol. Mar. 60, 445-451.

Collin B. 1909. Diagnoses preliminaries d'Acinetiens nouveaux ou mal connus. C.R. Hebd. Seances Acad. Sci. 149, 1094-1095.

Dovgal I.V. 2002. Evolution, phylogeny and classification of Suctorea (Ciliophora). Protistology. 2, 194-270.

Dovgal I.V. 2013. Suctorians (Ciliophora, Suctorea). In: Fauna of Ukraine, vol. 36. Ciliates. Issue 1. Naukova Dumka, Kiev (In Russian with English summary).

Dovgal I., Chatterjee T. and Ingole B. 2008. An overview of suctorian ciliates (Ciliophora, Suctorea) as epibionts of halacarid mites (Acari: Halacaridae). Zootaxa. 1810, 60-68.

Dovgal I., Chatterjee T. and Ingole B. 2009 New records of Thecacineta cothurnioides and Trematosoma rotunda (Ciliophora, Suctorea) as epibionts on nematodes from Indian Ocean. Protistology. 6, 19-23. 
Fisher R. 2003. Ciliate hitch-hikers-nematode ecto-commensals from tropical Australian sea-grass meadows. J. Mar. Biolog. Assoc. U.K. 83, 445-446.

Ghosh M. and Mandal S. 2019. Living with nematode: an epibiont Trematosoma rotunda associated with basibiont Desmodora scaldensis from Matla Estuary, Sundarbans, India. Thalassas. 35, 619-624.

Kalavati C. and Raman A.V. 2008. Taxonomy and ecology of protozoan from marginal marine environments of east coast of India. Rec. Zool. Surv. India, Occ. Paper 282, 1-136.
Radhakrishna G. 1984. Studies on some aspects of ecology of ciliates associated with algae of Visakhapatnam coast. Ph.D. Thesis. Andhra University.

Santhakumari V. 1985. Epizoic and ectoparasitic protozoans from planktonic copepods of the southwest and southeast coasts of India with the description of a new species. J. Mar. biol. Ass. India. 27, 29-38.

Santhakumari V. 1986. Two new species of the suctorians, Acineta satyanandanisp. nov. and Paracineta karunakarani sp. nov. epizoic on ostracodes. Indian J. Fish. 33, 471-475.

Address for correspondence: Igor Dovgal. A.O. Kovalevsky Institute of Biology of the Southern Seas RAS, Nakhimov Ave. 2, Sevastopol, 299011, Russia; e-mail:dovgal-1954@mail.ru 